medRxiv preprint doi: https://doi.org/10.1101/2021.03.12.21252149; this version posted March 15, 2021. The copyright holder for this preprint (which was not certified by peer review) is the author/funder, who has granted medRxiv a license to display the preprint in perpetuity.

It is made available under a CC-BY-NC-ND 4.0 International license .

\title{
1 Durability of SARS-CoV-2-specific IgG responses in saliva for up to 8 months after infection
}

2 Pranay R. Randad ${ }^{1}$, Nora Pisanic ${ }^{1}$, Kate Kruczynski ${ }^{1}$, Tyrone Howard ${ }^{1}$ Magdielis Gregory Rivera $^{1}$,

3 Kristoffer Spicer ${ }^{1}$, Annukka A.R. Antar ${ }^{2}$, Tristan Penson ${ }^{2}$, David L. Thomas ${ }^{2}$, Andrew Pekosz ${ }^{1,3}$, Nelson

$4 \quad$ Ndahiro $^{4}$, Lateef Aliyu ${ }^{4}$, Michael J. Betenbaugh ${ }^{4}$, Hannah Manley $^{5}$, Barbara Detrick ${ }^{5,6}$, Morgan Katz ${ }^{2}$,

5 Sara Cosgrove ${ }^{2}$, Clare Rock $^{2}$, Israel Zyskind ${ }^{7}$, Jonathan I. Silverberg $^{8}$, Avi Z. Rosenberg ${ }^{6}$, Priya Duggal ${ }^{5,9}$,

6 Yukari C. Manabe ${ }^{2,3}$, Matthew H. Collins ${ }^{10}$, Christopher D. Heaney ${ }^{1,5,9}$

$7 \quad{ }^{1}$ Department of Environmental Health and Engineering, Bloomberg School of Public Health, Johns

8 Hopkins University, Baltimore, Maryland, USA

$9 \quad{ }^{2}$ Division of Infectious Diseases, Department of Medicine, School of Medicine, Johns Hopkins

10 University, Baltimore, Maryland, USA

$11{ }^{3}$ Department of Molecular Microbiology and Immunology, Bloomberg School of Public Health, Johns

12 Hopkins University, Baltimore, Maryland, USA

$13{ }^{4}$ Department of Chemical and Biomolecular Engineering, Whiting School of Engineering, Johns Hopkins

14 University, Baltimore, Maryland, USA

$15{ }^{5}$ Department of Epidemiology, Bloomberg School of Public Health, Johns Hopkins University, Baltimore, 16 Maryland, USA

$17{ }^{6}$ Department of Pathology, School of Medicine, Johns Hopkins University, Baltimore, Maryland, USA

$18 \quad{ }^{7}$ Department of Pediatrics, NYU Langone Medical Center, New York, NY and Maimonides Medical

19 Center, Brooklyn, NY

$20{ }^{8}$ Department of Dermatology, George Washington University School of Medicine and Health Sciences,

21 Washington, DC 
medRxiv preprint doi: https://doi.org/10.1101/2021.03.12.21252149; this version posted March 15, 2021. The copyright holder for this preprint (which was not certified by peer review) is the author/funder, who has granted medRxiv a license to display the preprint in perpetuity. It is made available under a CC-BY-NC-ND 4.0 International license.

$22{ }^{9}$ Department of International Health, Bloomberg School of Public Health, Johns Hopkins University,

23 Baltimore, Maryland, USA

$24{ }^{10}$ The Hope Clinic of the Emory Vaccine Center, Division of Infectious Diseases, Department of

25 Medicine, Emory University School of Medicine, Decatur, Georgia, USA

26 Corresponding authors: Pranay R. Randad and Christopher D. Heaney, Department of Environmental

27 Health and Engineering, Johns Hopkins Bloomberg School of Public Health, 615 N. Wolfe St., W7033B,

28 Baltimore, MD USA, E-mail: prandad1@jhmi.edu \& cheaney1 @jhu.edu Phone: (443) 287-4989 
medRxiv preprint doi: https://doi.org/10.1101/2021.03.12.21252149; this version posted March 15, 2021. The copyright holder for this preprint (which was not certified by peer review) is the author/funder, who has granted medRxiv a license to display the preprint in perpetuity.

It is made available under a CC-BY-NC-ND 4.0 International license .

\section{KEYWORDS}

SARS-CoV-2, COVID-19, saliva, oral fluid, antibody, antibody testing, durability

ACKNOWLEDGEMENTS

Funding was provided by the Johns Hopkins COVID-19 Research and Response Program, the

FIA Foundation, a gift from the GRACE Communications Foundation (C.D.H., P.R.R., N.P., K.K.),

NIAID grants R21AI139784 (C.D.H. and N.P), National Institute of Environmental Health Sciences

(NIEHS) grant R01ES026973 (C.D.H., N.P., K.K.), NIAID grant R01AI130066 and NIH grant U24OD023382 (C.D.H), CDC epicenter grant (C.R., M.K., S.C.), NIAID grant 3R01AI148049 (P.D.,

D.L.T.), the Johns Hopkins University School of Medicine COVID-19 Research Fund, the Sherrilyn and

Ken Fisher Center for Environmental Infectious Diseases Discovery Program, and NIH grants

U54EB007958-12, U5411090366, U54HL143541-02S2, and UM1AI068613 (Y.C.M.), National Institute

for Innovation in Manufacturing Biopharmaceuticals (NIIMBL) and U.S. U.S. Department of commerce,

NIST award 70NANB20H037 (M.B., N.N., L.A.), and NIH/NIAID Center of Excellence in Influenza

Research and Surveillance contract HHS N2772201400007C (A.P.). The funders had no role in study design, data analysis, decision to publish, or preparation of the manuscript.

\section{AUTHOR CONTRIBUTIONS}

All authors reviewed and edited all sections of the article. P.R.R. conducted all data analysis and developed the manuscript. N.P. generated data, optimized data analysis algorithms and curated the data

47 set. K.K. handled laboratory logistics and generated data. A.Z.R., I.Z., J.I.S., M.K., P.D., Y.C.M., and concept.

All other authors declare that they have no actual or potential competing financial interests. 
medRxiv preprint doi: https://doi.org/10.1101/2021.03.12.21252149; this version posted March 15, 2021. The copyright holder for this preprint (which was not certified by peer review) is the author/funder, who has granted medRxiv a license to display the preprint in perpetuity. It is made available under a CC-BY-NC-ND 4.0 International license.

\section{ABSTRACT}

We evaluated the durability of IgG responses specific to SARS-CoV-2 nucleocapsid (N), receptor

54 binding domain (RBD), and spike (S) antigens in saliva up to 8 months after RT-PCR-confirmed COVID-

5519 using a multiplex salivary assay. We estimated a half-life of 64 days (d) (95\% CI: 49, 80 d) for N, 100

$56 \mathrm{~d}$ for RBD (95\% CI: 58, $141 \mathrm{~d}$ ), and $148 \mathrm{~d}$ (95\% CI: 62, $238 \mathrm{~d}$ ) for S IgG responses in saliva, consistent

57 with half-life estimates previously reported in blood. Saliva can serve as an alternative to blood to

58 monitor humoral immune responses on a large scale following SARS-CoV-2 infection and vaccination

59 for surveillance and assessment of population immunity. 
medRxiv preprint doi: https://doi.org/10.1101/2021.03.12.21252149; this version posted March 15, 2021. The copyright holder for this preprint (which was not certified by peer review) is the author/funder, who has granted medRxiv a license to display the preprint in perpetuity.

It is made available under a CC-BY-NC-ND 4.0 International license .

\section{MAIN TEXT}

There is a critical role for robust techniques to track humoral responses on a large scale following SARS-CoV-2 infection and vaccination for surveillance and assessment of population immunity. We previously developed and validated a multiplex bead-based immunoassay for detecting antibody responses to SARS-CoV-2 N, RBD, and S antigens in oral fluid (hereafter, saliva). ${ }^{1,2}$ In this study, we apply this salivary assay to 531 saliva samples from 341 individuals up to 8 months after RT-PCRconfirmed SARS-CoV-2 infection to evaluate the durability of SARS-CoV-2 IgG responses. We hypothesized that the durability of SARS-CoV-2 N, RBD, and S IgG in saliva would exceed at least six months, comparable to those reported in blood. ${ }^{3-5}$

SARS-CoV-2 N, RBD, and S IgG and the sum of their signal-to-cut off values $(\Sigma[\mathrm{S} / \mathrm{CO}])$ values peaked in saliva at $\sim 30$ days post symptom onset (DPSO) (Fig. 1a). A linear fit was used to model the decay of SARS-CoV-2 N, RBD, and S IgG in saliva over time among saliva collected $\geq 30$ DPSO (268 saliva samples from 237 people) (Supplementary Table 1). ${ }^{4}$ The estimated half-life was 64 days (d) (95\% CI: 49, 80 d) for $\mathrm{N} \Sigma(\mathrm{S} / \mathrm{CO}), 100 \mathrm{~d}(\mathrm{CI}: 58,141 \mathrm{~d})$ for RBD $\Sigma(\mathrm{S} / \mathrm{CO})$, and $148 \mathrm{~d}(95 \% \mathrm{CI}: 59,238$ d) for $\mathrm{S} \Sigma(\mathrm{S} / \mathrm{CO})$ (Fig. 1a, Supplementary Table 2). RBD and $\mathrm{S} \Sigma(\mathrm{S} / \mathrm{CO})$ were more stable over time compared to $\mathrm{N}$. These half-life estimates for salivary IgG are similar with those reported for circulating antibodies in plasma: 67 d (95\% CI: 49, 105 d) for $\mathrm{N} \mathrm{IgG,} 83 \mathrm{~d}(95 \% \mathrm{CI}: 62,127 \mathrm{~d})$ for RBD IgG, and $140 \mathrm{~d}(95 \% \mathrm{CI}: 89,329 \mathrm{~d})$ for $\mathrm{S} \mathrm{IgG} .^{4}$

Most saliva samples from COVID-19 subjects were positive for SARS-CoV-2 N (223/242; 92\%), RBD (231/242; 95\%), and S (224/242; 93\%) IgG between 1-6 months post symptom onset (31-180 d) (Fig. 1b). The proportion of saliva samples positive for N, RBD, and $\mathrm{S}$ IgG from 6-8 months post symptom onset (181-259 d) was 32\% (7/22), 68\% (15/22) and 59\% (13/22), respectively. Using the combined N/RBD/S IgG $\Sigma[\mathrm{S} / \mathrm{CO}]$, positivity for SARS-CoV-2 IgG was 98\% (236/242; 117 from females and 122 from males) between 1-6 months, and 73\% (16/22; 10 from females and 12 from males) between 6-8 months (Fig. 1b), indicating that most COVID-19 subjects are positive for SARS-CoV-2 IgG in 
medRxiv preprint doi: https://doi.org/10.1101/2021.03.12.21252149; this version posted March 15, 2021. The copyright holder for this preprint (which was not certified by peer review) is the author/funder, who has granted medRxiv a license to display the preprint in perpetuity.

It is made available under a CC-BY-NC-ND 4.0 International license .

saliva up to 8 months post symptom onset and that incorporating the IgG response to multiple SARSCoV-2 antigens can improve the sensitivity of saliva-based SARS-CoV-2 antibody testing.

There was evidence of a sex-specific interaction for $\mathrm{N}$ IgG and $\Sigma[\mathrm{S} / \mathrm{CO}]$, with males having more durable N IgG levels in saliva over time compared to females ( $\mathrm{n}=265$ saliva samples, 128 from 112 females and 137 from 122 males) (Fig. 2a, Supplementary Table 3 and 4). In general, half-life estimates for N, RBD, and S IgG in saliva were longer in males than females (Supplementary Table 3). We detected a trend of elevated RBD $\operatorname{IgG}$ and $\Sigma[\mathrm{S} / \mathrm{CO}]$ in saliva of males compared to females (Supplementary Table 5), consistent with previous reports in blood., ${ }^{4,6,7}$

We observed elevated median $\mathrm{N}$ and $\mathrm{RBD} \operatorname{IgG}$ and $\Sigma[\mathrm{S} / \mathrm{CO}]$ values among symptomatic compared to asymptomatic COVID-19 subjects (Fig. 2b, Supplementary Table 6), suggesting that asymptomatic subjects may be less likely to have durable $\operatorname{IgG}$ responses in saliva. In this analysis, we restricted the number of samples used from symptomatic subjects to better match the more limited set available from asymptomatic subjects (93 total saliva samples analyzed from 93 subjects, 21 asymptomatic and 72 symptomatic, from 72-174 DPSO). These results are consistent with reports of elevated SARS-CoV-2 antibodies in blood among individuals with moderate/severe compared to asymptomatic/mild COVID-19., ${ }^{4,5}$ A larger set of saliva samples from asymptomatic COVID-19 subjects should be tested in future studies.

We chose to conduct a cross-sectional analysis to achieve a large sample size and include time points 6-8 months post symptom onset. Ideally, this analysis would be repeated in a large, longitudinal sample set should it come available. Strengths of this analysis include saliva samples ranging from 2-259 DPSO, allowing for analysis of durability for up to 8 months, and the use of optimized algorithms for analyzing SARS-CoV-2 IgG multiplex data in saliva.

These results demonstrate that SARS-COV-2 RBD and S IgG are durable in saliva for up to 8 months post symptom onset. Durability appears to be increased among males versus females and 
medRxiv preprint doi: https://doi.org/10.1101/2021.03.12.21252149; this version posted March 15, 2021. The copyright holder for this preprint (which was not certified by peer review) is the author/funder, who has granted medRxiv a license to display the preprint in perpetuity.

It is made available under a CC-BY-NC-ND 4.0 International license .

symptomatic vs. asymptomatic SARS-CoV-2 infections. These results are consistent with what has been

previously reported in blood $^{3,4}$. Overall, these results support the utility of saliva as an accurate and noninvasive alternative to blood for longitudinal SARS-CoV-2 antibody testing and large-scale surveillance.

\section{METHODS}

Saliva samples were collected from participants enrolled into five groups of cohorts, which are

114 described in the Supplementary Text, along with methods for saliva sample collection, processing,

115 testing, and analysis for SARS-CoV-2 IgG in saliva using a 23-plex bead-based multiplex assay.

We calculated the median fluorescence intensity (MFI) signal-to-cutoff (S/CO) for seven

117 individual SARS-CoV-2 antigens, using MFI cut-off values derived using a set of pre-pandemic saliva

118 samples collected before January 2019 (n=265 saliva samples) (Supplementary Table 7). The $\Sigma[\mathrm{S} / \mathrm{CO}]$

119 for two N antigens (NAC N and Gen N), three RBD antigens (Sino RBD, Gen RBD and Mt. Sinai RBD),

120 two S antigens (Sino ECD and Mt. Sinai S), and all seven antigens (N/RBD/S) were used to estimate

121 SARS-CoV-2 IgG durability in saliva over time. Antibody durability was also analyzed with each antigen

122 separately using blank subtracted MFI values. Saliva samples with $<15 \mathrm{ug} / \mathrm{ml}$ of total IgG were excluded

123 from analysis. Loess splines were used to visualize the kinetics of IgG in saliva over DPSO. The RT-PCR

124 test date was used if symptom onset data was not available. To allow for comparability with previous

125 studies in blood, ${ }^{4}$ a generalized linear model, clustered on individual to account for multiple samples, was

126 used to model the durability of SARS-CoV-2 IgG in saliva. $\log _{2}$ transformed data was used to estimate

127 IgG half-life (-1/ $\beta$ coefficient $){ }^{4}$ For sex analysis, interaction was tested using a likelihood-ratio test. A

128 generalized linear model adjusted for DPSO and clustered on individual was used to compare SARS-

129 CoV-2 IgG levels by sex. A Wilcoxon-Mann-Whitney test was used to compare SARS-CoV-2 IgG levels

130 by symptoms. 
medRxiv preprint doi: https://doi.org/10.1101/2021.03.12.21252149; this version posted March 15, 2021. The copyright holder for this preprint (which was not certified by peer review) is the author/funder, who has granted medRxiv a license to display the preprint in perpetuity.

It is made available under a CC-BY-NC-ND 4.0 International license .

\section{REFERENCES}

132 1. Pisanic, N. et al. COVID-19 serology at population scale: SARS-CoV-2-specific antibody responses in saliva. J. Clin. Microbiol. (2020). doi:10.1128/JCM.02204-20

134 2. Heaney, C. D. et al. Comparative performance of multiplex salivary and commercially available serologic assays to detect SARS-CoV-2 IgG and neutralization titers. medRxiv : the preprint server for health sciences (2021). doi:10.1101/2021.01.28.21250717

137

3. Isho, B. et al. Persistence of serum and saliva antibody responses to SARS-CoV-2 spike antigens in COVID-19 patients. Sci. Immunol. 5, (2020).

4. Dan, J. M. et al. Immunological memory to SARS-CoV-2 assessed for up to 8 months after infection. Science (80-. ). eabf4063 (2021). doi:10.1126/science.abf4063

5. Ripperger, T. J. et al. Orthogonal SARS-CoV-2 Serological Assays Enable Surveillance of LowPrevalence Communities and Reveal Durable Humoral Immunity. Immunity 53, 925-933.e4 (2020).

144 6. Piccoli, L. et al. Mapping Neutralizing and Immunodominant Sites on the SARS-CoV-2 Spike Receptor-Binding Domain by Structure-Guided High-Resolution Serology. Cell 183, 10241042.e21 (2020).

147 7. Robbiani, D. F. et al. Convergent antibody responses to SARS-CoV-2 in convalescent individuals. Nature 584, 437-442 (2020). 
medRxiv preprint doi: https://doi.org/10.1101/2021.03.12.21252149; this version posted March 15, 2021. The copyright holder for this preprint (which was not certified by peer review) is the author/funder, who has granted medRxiv a license to display the preprint in perpetuity.

It is made available under a CC-BY-NC-ND 4.0 International license .

Figure 1. SARS-CoV-2-specific IgG responses in saliva over time.

(a) $\log _{10}$ median fluorescence intensity (MFI) of SARS-CoV-2-specific IgG responses to nucleocapsid $(\mathrm{N})$, receptor binding domain $(\mathrm{RBD})$, spike $(\mathrm{S})$, and $\Sigma[\mathrm{S} / \mathrm{CO}]$ values among $\mathrm{n}=531$ saliva samples (from n=341 COVID-19 cases) over time. The solid black line represents temporal kinetics (estimated by loess spline). Dashed blue line represents the estimated slope with half-life $\left(t_{1 / 2}\right)$ and $95 \%$ confidence interval using a linear fit model ( $\mathrm{n}=268$ saliva samples from 237 cases). Dashed gray lines indicate cut-off values. Hollow orange and gray circles represent saliva samples classified as positive or negative, respectively.

Note. $\log _{10}$ data is shown for all plots; $\Sigma[\mathrm{S} / \mathrm{CO}]$, sum of signal to cut-off; NAC, Native Antigen Company; Gen, GenScript; Sino, SinoBiological.

Figure 2. SARS-CoV-2-specific IgG responses in saliva over time, by sex and COVID-19 symptoms status.

(a) Nucleocapsid (N) $\operatorname{IgG} \Sigma[\mathrm{S} / \mathrm{CO}]$, receptor binding domain (RBD) $\operatorname{IgG} \Sigma[\mathrm{S} / \mathrm{CO}]$, spike (S) $\Sigma[\mathrm{S} / \mathrm{CO}]$, and N/RBD/S $\Sigma[\mathrm{S} / \mathrm{CO}]$ in saliva over time, by sex (n=528 saliva samples, 234 from 127 females and 294 from 211 males). Hollow light-blue and maroon circles represent males and females, respectively. Lightblue and maroon lines represent the linear fit for males and females, respectively ( $n=265$ saliva samples, 128 from 112 females and 137 from 122 males). $p$ values were estimated via likelihood-ratio test. (b) $\mathrm{N}$ $\operatorname{IgG} \Sigma[\mathrm{S} / \mathrm{CO}], \mathrm{RBD} \operatorname{IgG} \Sigma[\mathrm{S} / \mathrm{CO}], \mathrm{S} \Sigma[\mathrm{S} / \mathrm{CO}]$, and N/RBD/S $\Sigma[\mathrm{S} / \mathrm{CO}]$ in saliva by symptoms (93 saliva samples from 93 COVID-19 cases, 21 asymptomatic and 72 symptomatic, ranging from 72-174 DPSO). $p$

169 values represent comparison of medians between groups via Wilcoxon-Mann-Whitney test. Box gray 170 lines represent $25^{\text {th }}, 50^{\text {th }}$, and $75^{\text {th }}$ percentile. Note. $\log _{10}$ data is shown for all plots; $\Sigma[\mathrm{S} / \mathrm{CO}]$, sum of 171 signal to cut-off; NAC, Native Antigen Company; Gen, GenScript; Sino, Sino Biological. 


\section{Figure 1}

a

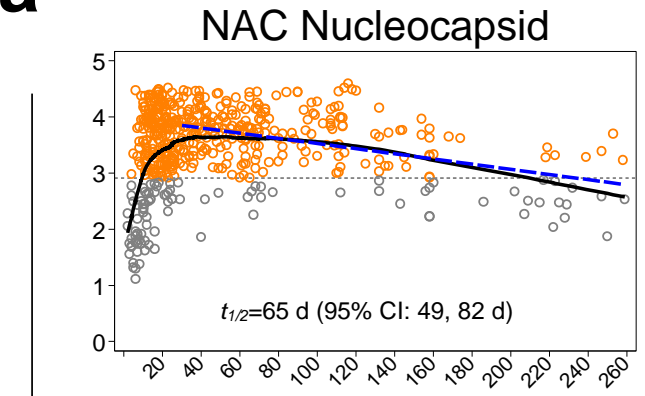

Sino Receptor binding domain

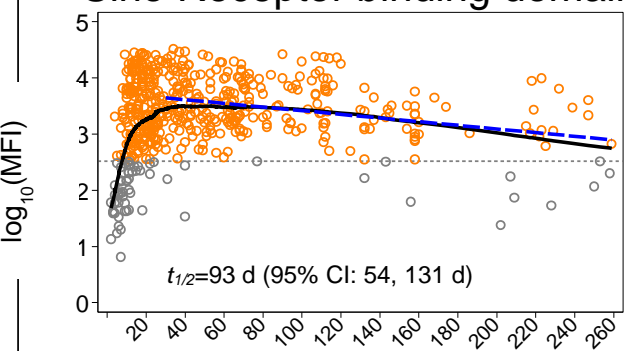

Sino Spike ectodomain (ECD)
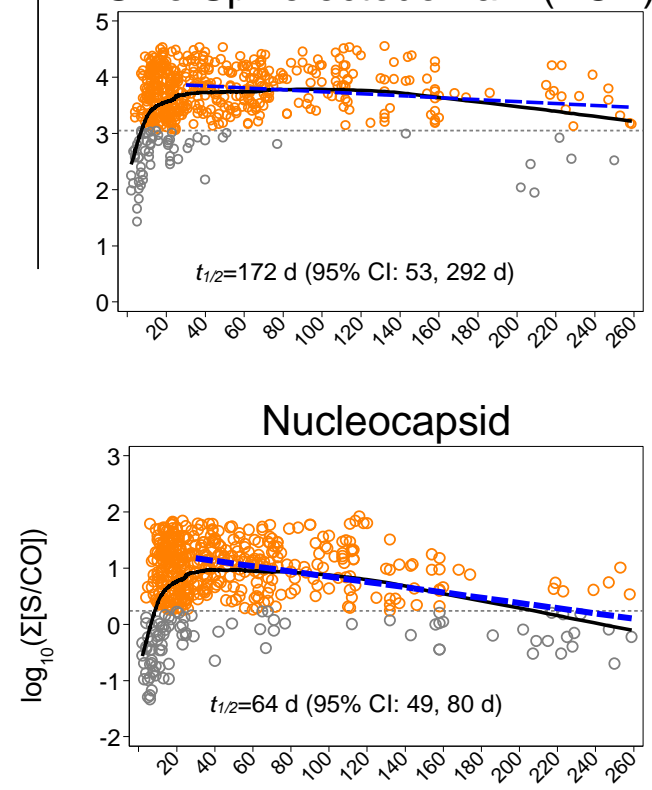

Gen Nucleocapsid

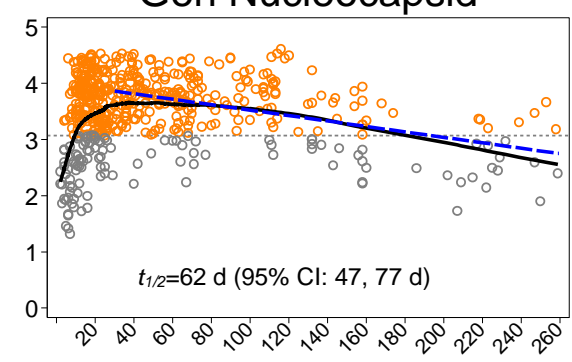

Gen Receptor binding domain

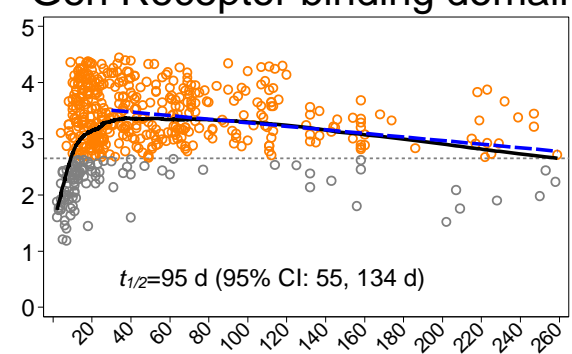

\section{Mt. Sinai Spike}

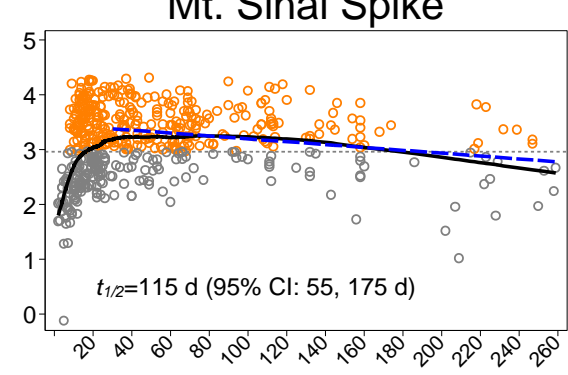

Receptor binding domain

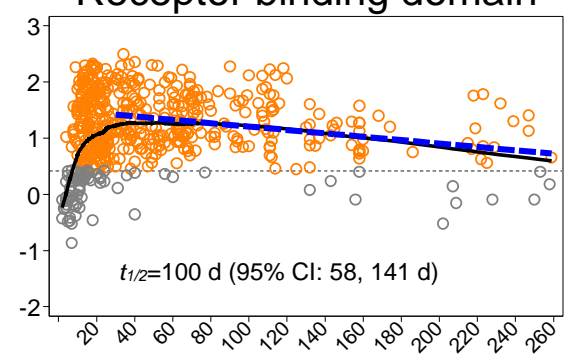

b

Days post symptom onset

\begin{tabular}{|c|c|c|c|c|}
\hline \multirow[t]{2}{*}{ Antigen } & \multicolumn{3}{|c|}{$\lambda^{\star} \leq 5^{3^{0}}$} & $1^{80}$ \\
\hline & 110 & 157 & 242 & 22 \\
\hline NAC N & 54 & 89 & 91 & 32 \\
\hline Gen N & 56 & 82 & 88 & 32 \\
\hline Sino RBD & 60 & 96 & 97 & 68 \\
\hline Gen RBD & 46 & 88 & 92 & 68 \\
\hline Mt. Sinai RBD & 46 & 75 & 90 & 59 \\
\hline Sino ECD & 66 & 92 & 96 & 73 \\
\hline Mt. Sinai S & 35 & 59 & 75 & 36 \\
\hline $\mathrm{N} \Sigma[\mathrm{S} / \mathrm{CO}]$ & 60 & 90 & 92 & 32 \\
\hline $\operatorname{RBD} \Sigma[S / C O]$ & 53 & 92 & 95 & 68 \\
\hline $\mathrm{S} \Sigma[\mathrm{S} / \mathrm{CO}]$ & 58 & 87 & 93 & 59 \\
\hline N/RBD/S $\Sigma[S / C O]$ & 67 & 96 & 98 & 73 \\
\hline
\end{tabular}

Days post symptom onset (days)
Mt. Sinai RBD

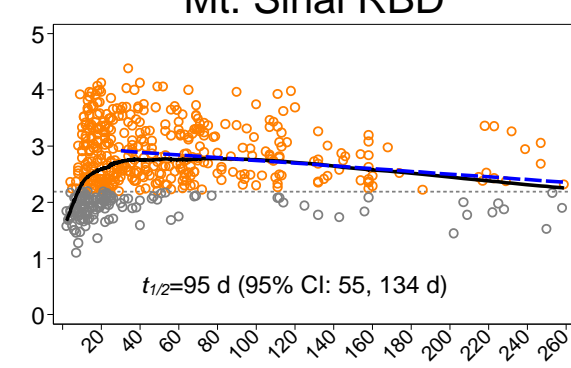
$\vartheta^{9}$
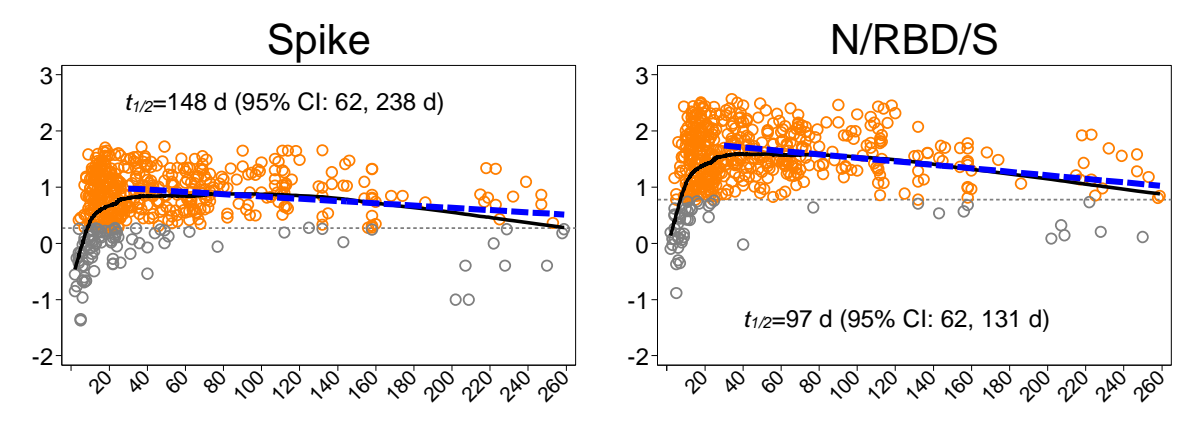

$\bigcirc$ antibody positive $\bigcirc$ antibody negative L- loess - - Fitted values 


\section{Figure 2}
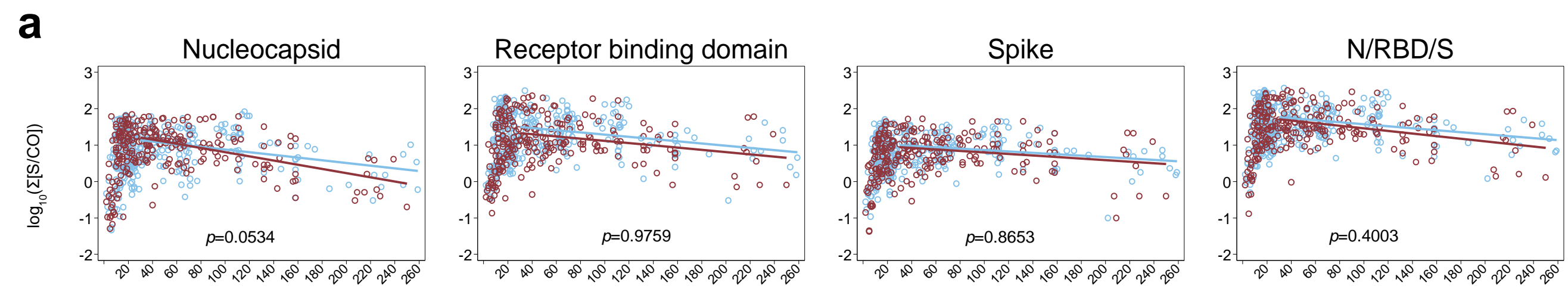

$\bigcirc$ Male $\bigcirc$ Female $\longrightarrow$ Male fitted values $\longrightarrow$ Female fitted values

b
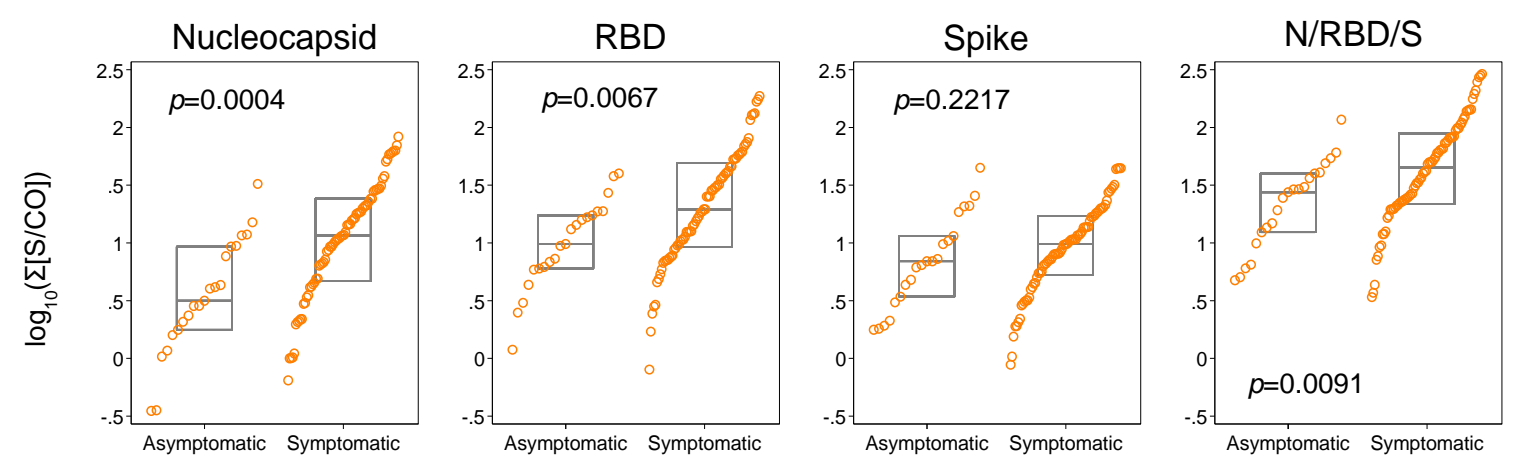